\title{
PERBAIKAN PROSES PRODUKSI UKM ROTI DI KOTA MEDAN MELALUI PENERAPAN DISIPLIN TEKNIK INDUSTRI
}

\author{
Rosnani Ginting $^{1}$, Ukurta Tarigan ${ }^{2}$, Erwin Sitorus ${ }^{3}$ \\ ${ }^{1}$ Fakultas Teknik, Universitas Sumatera Utara \\ email: rosnani_usu@yahoo.co.id \\ ${ }^{2}$ Fakultas Teknik, Universitas Sumatera Utara \\ email: ukurta.tarigan@yahoo.co.id \\ ${ }^{2}$ Fakultas Teknik, Universitas Sumatera Utara \\ email: erwin_birosdmusu@yahoo.com
}

\begin{abstract}
Abstrak. Tujuan khusus dari ini kegiatan pelayanan masyarakat adalah untuk memberikan pengetahuan tentang pentingnya meningkatkan kualitas kerja dengan menerapkan K3 dan melengkapi APD yag diperlukan, peningkatan kebersihan UKM dan proses produksi, pemahaman kesadaran menjaga pentingnya kerapian dengan menerapkan 5S, perbaikan sistem sirkulasi udara di ruang dan peralatan tambahan yang dibutuhkan Hasil dari komunitas ini kegiatan pelayanan sosialisasi mengenai pelaksanaan $\mathrm{K} 3,5 \mathrm{~S}$ dan prinsip-prinsip ilmu Teknik Industri Lainnya dianggap relevan dengan kegiatan produksi, perbaikan tata letak lantai produksi, penyediaan K3 dan Visual diplay sesuai dan memadai, bantu desain, sieving tepung, pengadaan peralatan seperti kipas angin, meja lipat dan papan nama di rak dan ruang peralatan, pengadaan peralatan dan publikasi ilmiah lainnya kebutuhn dengan menerbitkan jurnal ilmiah.
\end{abstract}

Kata Kunci : Kesehatan dan Keselamatan Kerja (K3), SME, 5S, Teknik Industri

\begin{abstract}
The specific objective of this community service activities is to give knowledge of the importance of improving the quality of work by applying K3 and equip PPE yag needed, improvement in the cleanliness of SMEs and the production process, an understanding of consciousness maintain the importance of neatness by implementing 5S, improvement in air circulation system in the room and additional equipment required. Outcomes of this community service activities are socialization regarding the implementation of $K 3$, $5 S$ and principles of science in Industrial Engineering Others considered relevant to production activities, improvement of the layout of the production floor, provision of $K 3$ and Visual diplay appropriate and adequate, design aids, sieving flour, procurement of equipment such as a fan, a folding table and a nameplate on a shelf and space equipment, procurement of equipment and other kebutuhn scientific publications by publishing scientific journals .
\end{abstract}

Keywords : health and safety at work (K3), SME, 5S, Industrial Engineering 


\section{PENDAHULUAN}

Perkembangan perusahaan industri di kota Medan sampai Tahun 2006 mengalami penurunan. Jumlah perusahaan industri sampai Tahun 2006 adalah 4.613 unit usaha dan perkembangan unit usaha pada Tahun 2001 terdaftar 180 unit usaha, sedangkan pada Tahun 2002 sebesar 178 unit usaha maka dalam hal ini terjadi penurunan sebesar 2 unit usaha.

Pada Tahun 2003 sebanyak 284 unit usaha, maka terjadi peningkatan sebesar 106 unit usaha dan pada Tahun 2004 berjumlah 341 unit usaha, maka terjadi peningkatan sebesar 57 unit usaha. Pada Tahun 2005 berjumlah 280 unit usaha maka terjadi penurunan sebesar 61 unit usaha dan pada Tahun 2006 adalah 243 unit usaha, terjadi penurunan sebesar 37 unit usaha (dinas perindustrian dan perdagangan kota medan, 2007)

Memang cukup berat tantangan yang dihadapi untuk memperkuat struktur perekonomi nasional. Pembinaan pengusaha kecil harus lebih diarahkan untuk meningkatan kemampuan pengusaha kecil menjadi pengusaha menengah. Namun, disadari pula bahwa pengembangan usaha kecil menghadapi beberapa kendala seperti kemampuan, keterampilan, keahlian, manajemen sumber daya manusia, kewirausahaan, pemasaran dan keuangan. Lemahnya kemampuan manajerial dan sumberdaya manusia ini mengakibatkan pengusaha kecil tidak mampu menjalankan usahanya dengan baik. Pertama, kelemahan dalam memperoleh peluang pasar dan memperbesar pasang pasar. Kedua, kelemahan dalam struktur pemodalan dan keterbatasan untuk memperoleh jalur terhadap sumber-sumber pemodalan. Ketiga, kelemahan di bidang organisasi dan manajemen sumber daya manusia. Keempat, Keterbatasan jaringan usaha kerjasama antar pengusaha kecil (system informasi pemasaran). Kelima, iklim usaha yang kurang kondusif, karena persaingan yang saling mematikan. Keenam, pembinaan yang telah dilakukan kurang terpadu dan kurangnya kepercayaan serta kepedulian masyarakat terhadap usaha kecil. Secara garis besar kelemahan pada bidang pemasaran di industri kecil makanan berharap dapat terus bertahan dalam berkompetisi dengan perusahaan-perusahaan sejenis lainnya.

Industri kecil dan menengah merupakan kegiatan ekonomi yang dilakukan oleh perseorangan atau rumah tangga maupun suatu badan yang bertujuan untuk memproduksi barang atau jasa untuk diperniagakan secara komersial, yang mempunyai kekayaan bersih paling banyak Rp. 200 juta dan nilai penjualan per Tahun kurang dari Rp. 50 milyar dengan jumlah tenaga kerja kurang dari 100 orang. Pada umumnya UKM di Indonesia tidak memiliki organisasi dan manajemen yang terstruktur. Usaha dijalankan dengan konsep-konsep sederhana, tradisional dan pada umumnya masih memegang prinsip-prinsip kekeluargaan.

Dewasa ini, di Indonesia terdapat tidak kurang dari 34 juta usaha kecil dan menengah (UKM) termasuk di dalamnya 2,1 industri kecil dan menengah. Oleh karena itu, pengembangan kemampuan UKM merupakan issue pembangunan yang sangat penting karena selain memiliki peranan strategis dalam pertumbuhan ekonomi maupun dalam pemerataan kesempatan serta pendistribusian hasilhasil pembangunan.

Disamping itu, upaya mengembangkan dan mensinergikan UKM dengan industri besar akan mengukuhkan ekonomi nasional secara menyeluruh. Pendekatan pemberdayaan industri kecil dan menengah sebagai mitra usaha besar perlu terus dikembangkan dengan penguatan pada kualitas sumber daya manusianya. Mengingat bahwa usaha kecil dan menengah pada umumnya berakar langsung pada masyarakat maka penanganannya harus senantiasa memperhitungkan berbagai aspek sosial dan budaya setempat.

\subsection{Identifikasi Masalah}

UKM ini merupakan industri yang mempunyai beberapa aspek dalam proses produksi yang masih perlu diperbaiki. Maka dapat diidentifikasi masalah sebagai berikut.

1. Kondisi ruangan yang panas

2. Kondisi bangunan yang sederhana

3. Kondisi tata letak peralatan dan bahan diletakkan sembarangan

4. Kondisi pencahayaan ruangan yang gelap

5. Tidak ada penerapan alat pelindung diri

6. Kebersihan ruangan yang tidak bersih

7. Tidak ada perawatan bangunan dan peralatan yang digunakan

8. Tata letak peralatan yang berserakan

9. Jam istirahat yang terlalu singkat

10. Tidak ada perhatian terhadap asuransi kesehatan

11. Tidak terdapat gudang penyimpanan produk

\section{TARGET DAN LUARAN}

2.1. Target

Adapun tujuan kegiatan dari Pengadian masyarakat ini adalah:

I. Tujuan Umum :

Penerapan Disiplin Ilmu Ergonomi untuk memperbaiki proses produksi pada industri Roti

II. Tujuan Khusus

1. Memberi pengetahuan pentingnya meningkatkan kualitas kerja dengan menerapkan K3 dan melengkapi APD yag dibutuhkan 
2. Perbaikan pada kebersihan UKM dan proses produksi

3. Memberi pemahaman kesadaran menjaga pentingnya kerapian dengan menerapkan 5S

4. Perbaikan pada sistem sirkulasi udara dalam ruangan

5. Penambahan peralatan yang dibutuhkan

\subsection{Luaran}

Luaran dari kegiatan pengabdian ini adalah:

1. Kegiatan sosialisasi mengenai penerapan K3, 5S dan prinsip-prinsip keilmuan Teknik Industri Lainnya yang dinilai relevan dengan kegiatan produksi.

2. Penyediaan alat K3 dan Visual Diplay yang sesuai dan memadai.

3. Pengadaan peralatan seperti keranjang

4. Perngadaan Peralatan Kebutuhan Lainnya

5. Publikasi ilmiah melalui penerbitan jurnal ilmiah.

\section{METODE PELAKSANAAN}

Metode yang digunakan dalam kegiatan pengabdian pada masyarakat ini dilakukan dalam bentuk Penerapan disiplin ilmu teknik industri Rancangan Teknik Industri ini akan dilakukan dalam bentuk:

I. Tahap Pre Test

Pada tahap ini dilakukan obsevasi terhadap industri kecil yaitu dengan :

1. Survey yang dilakukan dengan cara :

a. Pengamatan Langsung dengan menggunakan foto dan video

b. Kuisioner pada proses produksi pada pekerja dan pemilik industri roti

II. Tahap Rancangan Teknik Industri pada Industri Roti.

1. Sosialisasi rancangan Teknik Industri pada pemilik dan pekerja Industri Roti yaitu :

a. Sosialisasi cara pandang pemilik dan operator tentang perancangan Teknik Industri pada proses produksi yang dilakukan

b. Pelatihan 5S (Seiri, Seiso, Seiton, Seiketsu dan Shitsuke) pada lingkungan kerja di bagian produksi

2. Sosialisasi tentang Kesehatan dan Keselamatan Kerja (K3) dan alat pelindung diri

3. Pengadaan alat K3 dan Visual Display

4. Pengadaan Exhaust Fan

5. Pengadaan Kebutuhan Peralatan Lainnya

III. Tahap Post Test

Pada tahap ini dilakukan obsevasi terhadap industri kecil yaitu dengan :

1. Survey yang dilakukan dengan cara :
a. Pengamatan Langsung dengan menggunakan foto dan video

\section{KELAYAKAN}

Ketua Pelaksanaan Pengabdian Masyarakat : Ir. Rosnani Ginting MT megajarkan mata kuliah Rancangan Teknik Industri dan Sistem Produksi serta Praktikum Rancangan Teknik Industri dan Praktikum Sistem Produksi yang berada di Laboratorium Sistem produksi serta sebagai Kepala Laboratorium.

Dengan diadakannya pengabdian terhadap masyarakat, maka akan meningkatkan kompetensi dari Rancangan Teknik Industri dan menghubungkan kemitraan dari Departemen Teknik Industri, sehingga sesuai dengan visi Universitas Sumatera Utara yaitu sebagai BHMN yang menjadi profit center. Dan sebagai usulan pola produksi pada Industri untuk Departemen Perindustrian dan untuk Bank.

Ergonomi atau ergonomics ( bahasa Inggrisnya ) sebenarnya berasal dari kata yunani yaitu Ergo yang berarti kerja dan Nomos yang berarti hukum. Dengan demikian ergonomi dimaksudkan sebagai disiplin keilmuan yang mempelajari manusia dalam kaitannya dengan pekerjaan. Disiplin ergonomi secara khusus akan mempelajari keterbatasan dari kemampuan manusia dalam berinteraksi dengan teknologi dan produk-produk buatannya. Pendekatan ergonomi dalam perancangan stasiun dan/atau fasilitas kerja di industri telah menempatkan rancangan sistem kerja manusia-mesin yang awalnya serba rasional-mekanistik menjadi tampak lebih manusiawi. Disini faktor yang terkait dengan fisik (faal/fisiologi) maupun perilaku (psikologi) manusia baik secara individu pada saat berinteraksi dengan mesin dalam sebuah rancangan sistim manusia-mesin dan lingkungan kerja fisik akan dijadikan pertimbangan utama.

Anggota Tim Pertama Ir. Ukurta Tarigan, MT yang mempunyai keahlian Rancangan Teknik Industri dan Tata Letak Pabrik dan staf pada Laboratorium Tata Letak Pabrik dimana perbaikan layout diperlukan pada pangabdian ini.

Anggota Tim Erwin Siregar, ST. M.T memiliki keahlian di bidang Psikologi industri yang sangat mendukung dalam pengabdian ini.

\section{HASIL PELAKSANAAN \\ 5.1. Tahap Pre-Test}

Pada tahap ini dilakukan obsevasi terhadap industri kecil yaitu dengan :

a. Pengamatan Langsung dengan menggunakan foto dan video

b. Kuisioner pada proses produksi pada pekerja dan pemilik industri Roti.

c. Body Map Kuisioner pada pekerja untuk melihat keluhan kelelahan 
pekerja pada fasilitas kerja pada proses produksi.

d.

\subsubsection{Pengamatan Langsung}

Berikut ini adalah foto-foto hasil pengamatan langsung.

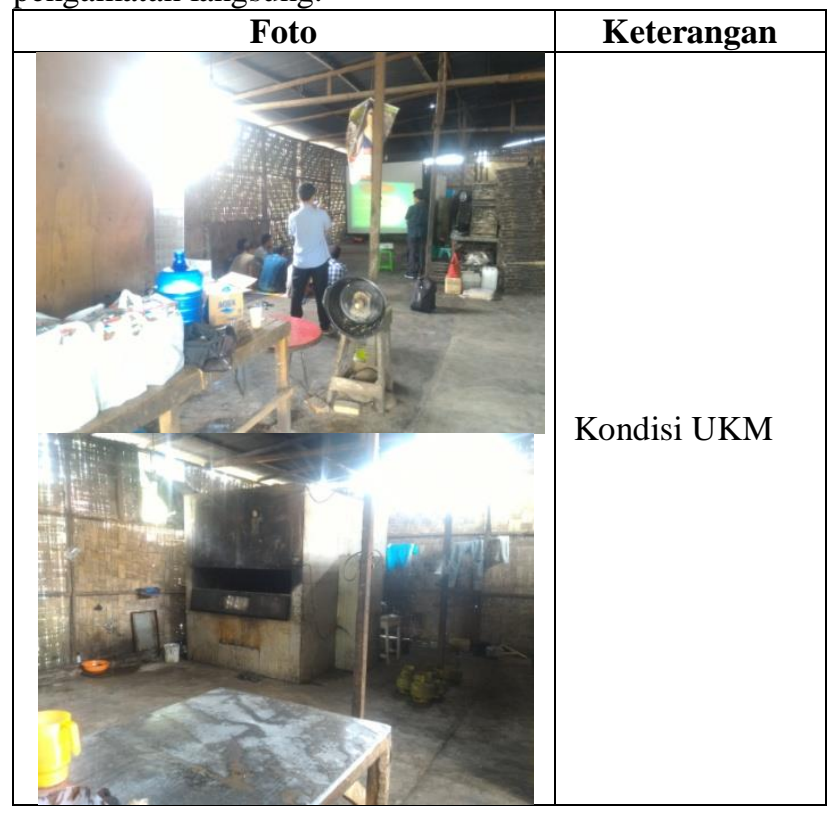

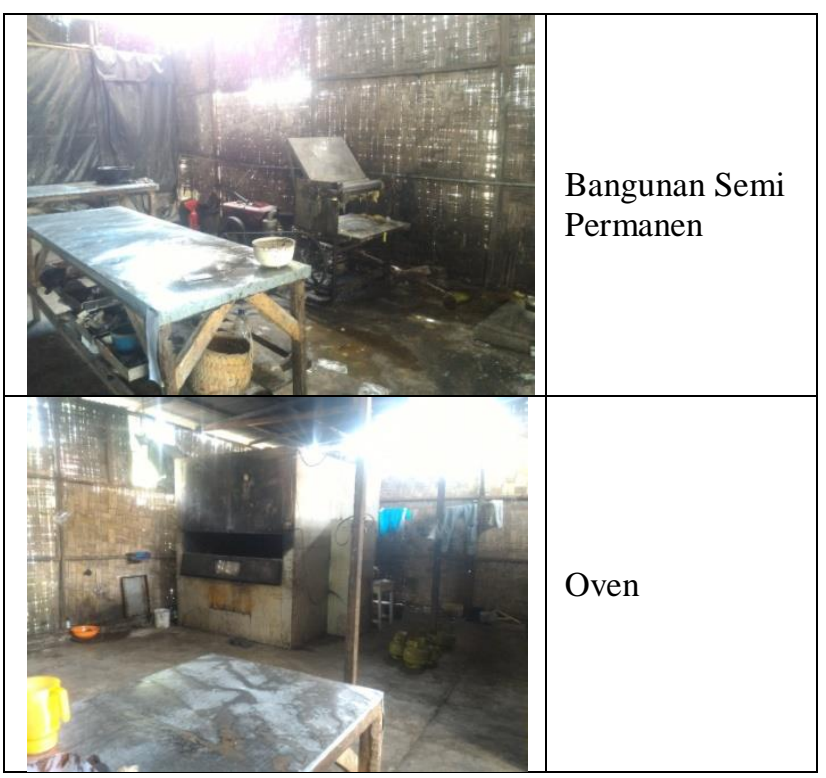

5.1.2 Kuisioner pada proses produksi pada pekerja dan pemilik industri.

Tahapan berikutnya ialah melakukan interview mengenai sistem manufaktur yang ada di UKM terhadap para pekerja dan pemilik.

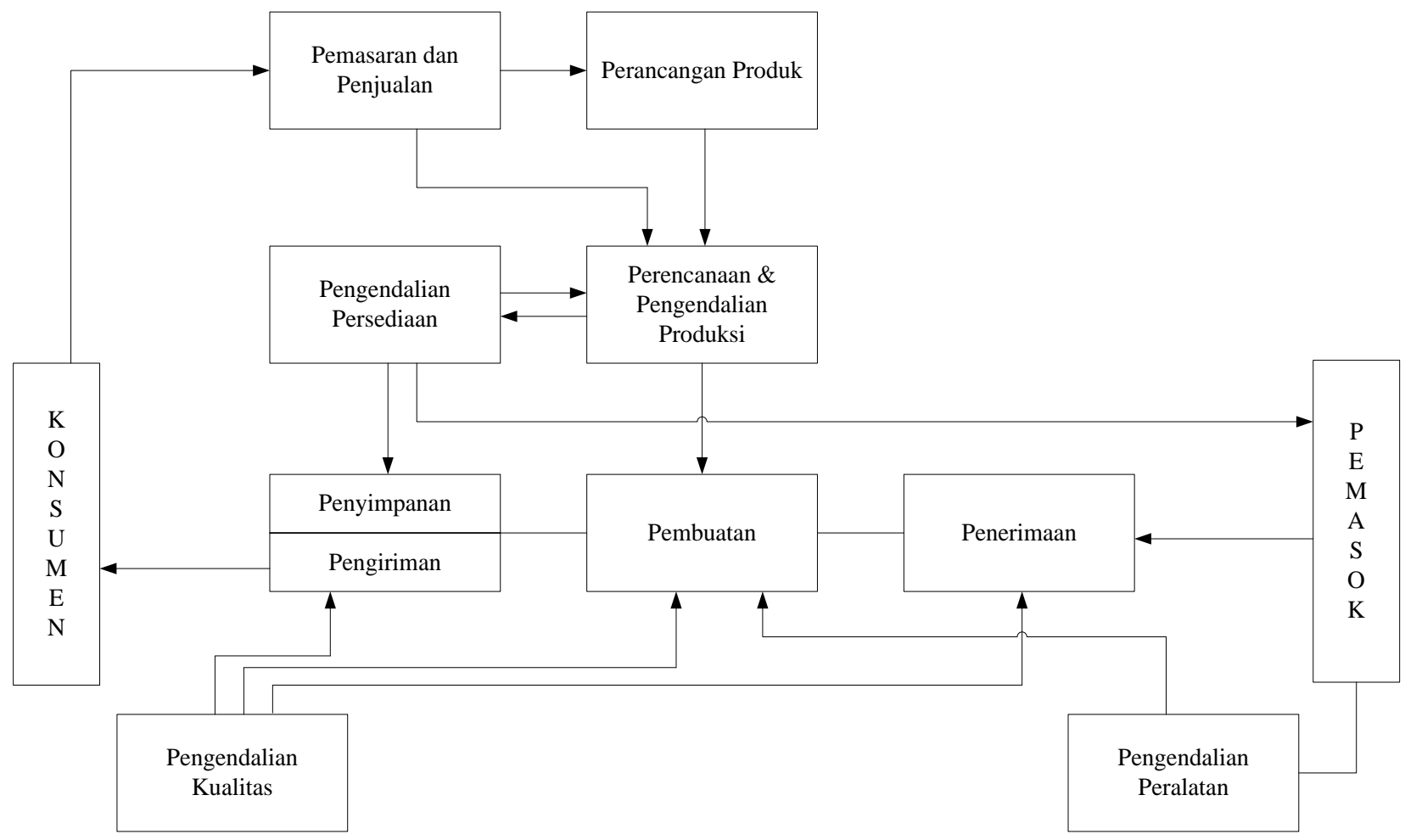

Gambar Siklus Manufaktur UKM 


\subsection{Tahap Rancangan Teknik Industri} pada Industri Roti

5.2.1 Sosialisasi Rancangan Teknik Industri Pada Pemilik Dan Pekerja Industri Roti

Perbaikan yang pertama yang akan dilakukan ialah berkaitan dengan keteraturan dan kerapian tempat kerja. Tempat produksi juga digunakan sebagai rumah atau kediaman dari pemilik. Hal ini menyebabkan kondisi UKM menjadi tidak rapi dan tidak teratur.

Sosialisasi dan pelatihan $5 \mathrm{~S}$ dilakukan terhadap pemilik dan pekerja yang ada di UKM tersebut. UKM diberikan pemahaman akan pentingnya penerapan $5 \mathrm{~S}$ dan prinsip-prinsip $\mathrm{K} 3$ dan kemudian dimotivasi agar diterapkan dalam setiap kegiatan produksi. Baik pemilik maupun pekerja mulai memahami pentingnya penerapan $5 \mathrm{~S}$ dan secara perlahan namun berkelanjutan mencoba menerapkannya.

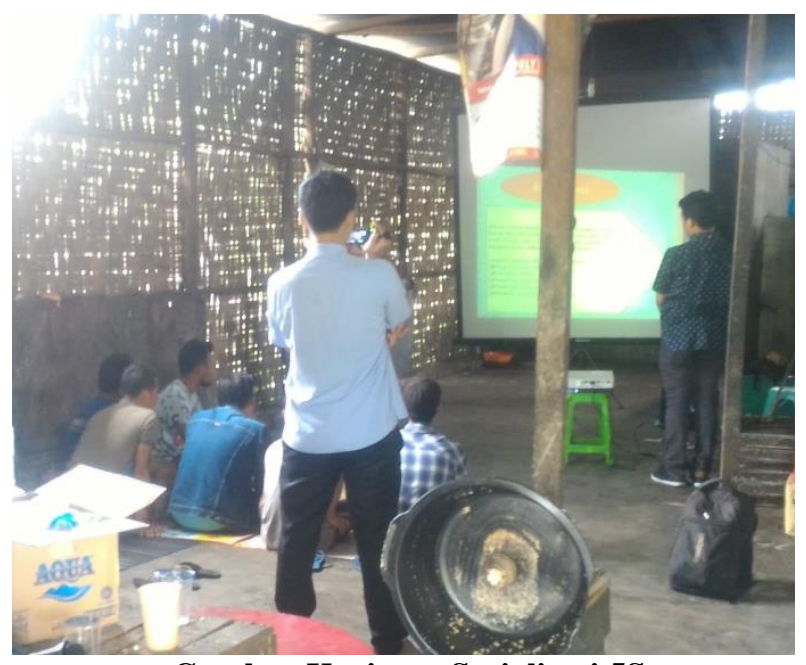

Gambar Kegiatan Sosialisasi 5S

\subsubsection{Sosialisasi Tentang Kesehatan Dan \\ Keselamatan Kerja (K3) Dan Alat \\ Pelindung Diri}

Pelatihan K3 dilakukan dengan memberikan presentasi mengenai Kesehatan Dan Keselamatan Kerja. Presentasi diberikan di lokasi kerja dan diikuti oleh pemilik dan seluruh pekerja. Meskipun belum sempurna, namun atensi yang baik dari pemilik dan pekerja terhadap pentingnya K3 dan manfaatnya akan sangat berguna untuk penerapan K3 secara kontinu.

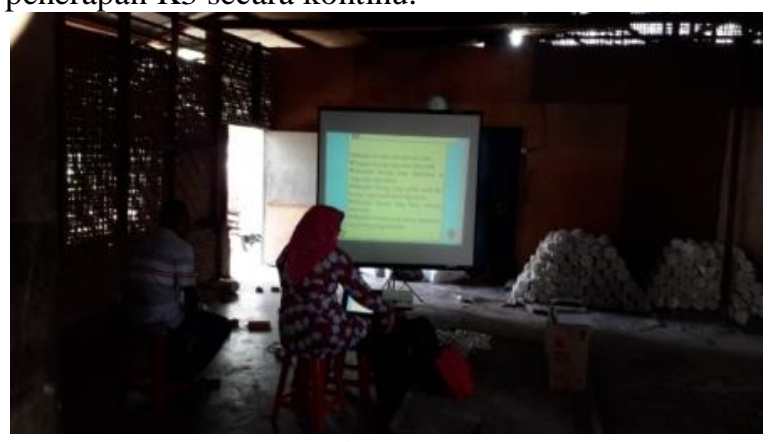

Gambar Sosialisasi K3

\subsubsection{Pengadaan APD}

Setelah melalui diskusi terhadap pemilik dan pekerja mengenai kebutuhan alat pelindung diri, maka dilakukan pengadaan alat sebagai berikut:
a. Masker
b. Sarung tangan
c. Kaos untuk para pekerja

d. Celemek

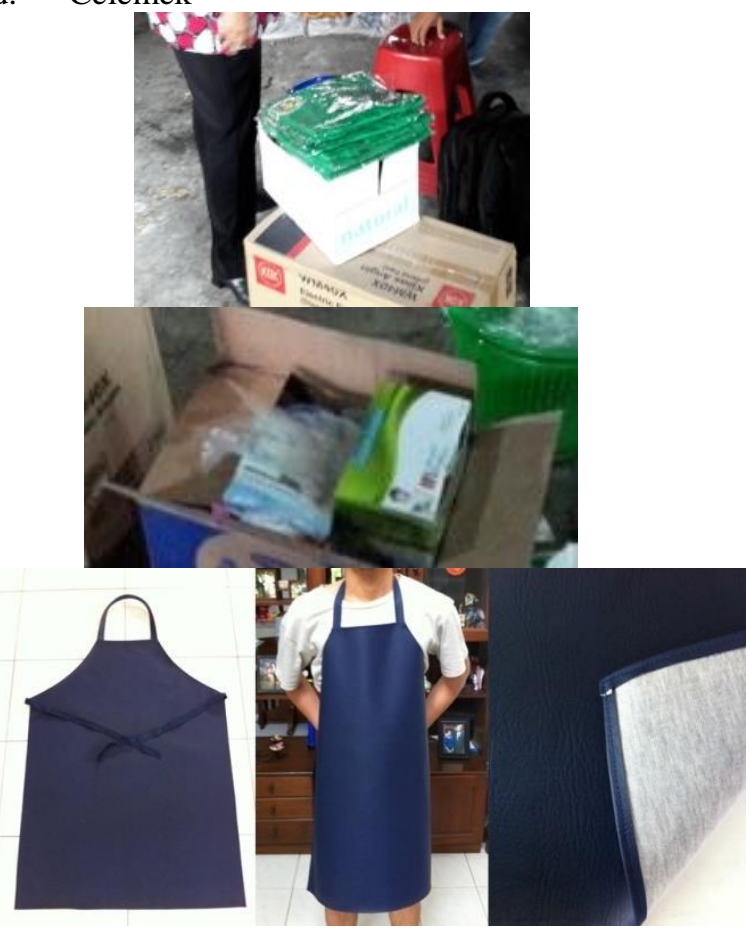

\section{Gambar Pengadaan Alat Pelindung Diri}

\subsubsection{Pengadaan Peralatan yang dibutuhkan}

Kegiatan selanjutnya ialah pengadaan peralatan yang dibutuhkan oleh UKM, seperti Keranjang, Penyegel Kemasan serta Kipas Angin dan Kursi plastik.

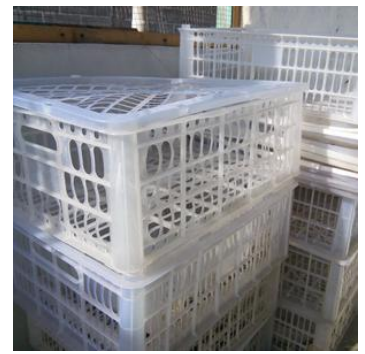



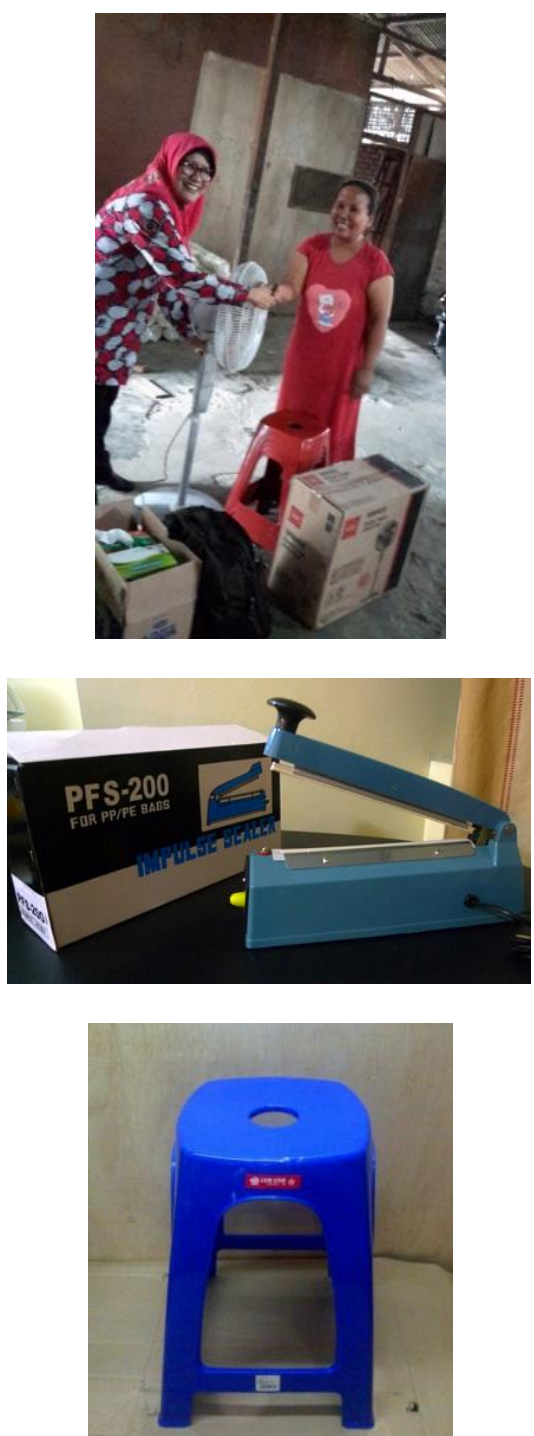

Gambar Pengadaan Peralatan

\subsection{Tahap Post-Test}

Pada tahap ini dilakukan obsevasi terhadap industri kecil yaitu dengan :

a. Pengamatan Langsung dengan menggunakan foto dan video

Berikut ini adalah foto-foto hasil pengamatan langsung.

Tabel Pengamatan Langsung

\begin{tabular}{|l|l|}
\hline \multicolumn{1}{|c|}{ Foto } & $\begin{array}{l}\text { Keteranga } \\
\mathbf{n}\end{array}$ \\
\hline & $\begin{array}{l}\text { Kondisi } \\
\text { kebersihan } \\
\text { yang lebih } \\
\text { baik } \\
\text { daripada } \\
\text { sebelumny } \\
\text { a sebagai } \\
\text { bukti } \\
\text { adanya } \\
\text { penerapan } \\
5 \mathrm{~S}\end{array}$ \\
\hline
\end{tabular}

Jurnal Sistem Teknik Industri, Vol 18. No. 2, Juli 2016

ISSN 1411 - 5247

ISSN Online 2527-9408

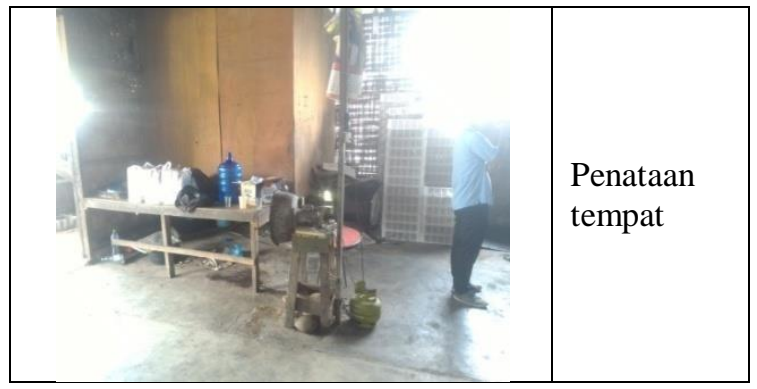

\section{KESIMPULAN}

1. Industri Roti ini merupakan industri yang mempunyai beberapa aspek dalam proses produksi yang masih perlu diperbaiki, dapat dilihat pada Lampiran Foto UKM. Kegiatan yang telah berhasil dilaksanakan pada UKM yaitu:

a. Sosialisasi cara pandang pemilik dan operator tentang perancangan Teknik Industri pada proses produksi yang dilakukan.

b. Pelatihan 5S (Seiri, Seiso, Seiton, Seiketsu dan Shitsuke) pada lingkungan kerja di bagian produksi.

c. Sosialisasi Tentang Kesehatan Dan Keselamatan Kerja (K3) Dan Alat Pelindung Diri

d. Pengadaan Alat K3

e. Pengadaan Fan

f. Pengadaan kaos

h. Pengadaan peralatan tambahan

\section{DAFTAR PUSTAKA}

Apple, James M. 1990. Tataletak Pabrik dan Pemindahan Bahan. Edisi Ketiga. Bandung: Penerbit ITB

Blankchard, Benjamin \& Walter J. Fabrycky. 1998. System Engineering and Analysis. Edisi Ketiga. New Jersey :Prentice Hall

Cross, Nigel. 2001. Engineering Design Methods: Strategies for Product Design. New York: John Wiley Publishing.

Purnomo, Hari. 2004. Pengantar Teknik Industri. Cet. I; Yogyakarta: Graha Ilmu.

Ginting, Rosnani. 2007. Sistem Produksi. Yogyakarta: Graha Ilmu

Sinulingga Sukaria, 2008. Pengantar Teknik Industri. Yogyakarta: Graha Ilmu 